Acta Universitatis Nicolai Copernici • Pedagogika XXXIV/2/2017

Nauki Humanistyczno-Społeczne • Zeszyt 440

DOI: http://dx.doi.org/10.12775/AUNC_PED.2017.017

Jarosław Przeperski

Uniwersytet Mikołaja Kopernika w Toruniu

\title{
NOWE PARADYGMATY \\ W OBSZARZE WSPARCIA RODZINY \\ W ŚRODOWISKU LOKALNYM W PERSPEKTYWIE \\ UMIESZCZANIA DZIECI W PIECZY ZASTĘPCZEJ
}

\begin{abstract}
pisywanie współczesnego świata staje się poważnym wyzwaniem także dla naukowców. Zmieniające się pojęcia rodziny i środowiska lokalnego powodują, że konieczne jest określenie tej rzeczywistości w nowy sposób. W niniejszym artykule chciałbym podjąć refleksję dotyczącą jednego z obszarów pedagogiki społecznej, pedagogiki rodziny i pracy socjalnej, jakim jest umieszczanie dzieci w pieczy zastępczej w ujęciu familiocentrycznym.

Duża liczba dzieci umieszczanych w pieczy zastępczej stanowi w Polsce od wielu lat ważny problem społeczny. Politycy społeczni, pedagodzy, pracownicy socjalni, a także środowiska naukowe próbują, na podstawie badań, formułować tezy pozwalające na zrozumienie i przezwyciężenie tego negatywnego zjawiska. Ogólna liczba dzieci przebywających w 2015 r. w pieczy zastępczej wynosiła 77 509¹, z tego 20743 było wychowankami instytucjonalnej pieczy zastępczej
\end{abstract}

${ }^{1}$ Dane Ministerstwa Rodziny, Pracy i Polityki Społecznej, https://www. mpips. gov. pl/wsparcie-dla-rodzin-z-dziecmi/opieka-zastepcza-nad-dzieckiem/ dane-statystyczne/. 
w 1046 placówkach. Oznacza to, że 73\% dzieci przebywało w rodzinnych formach opieki, a $27 \% \mathrm{w}$ instytucjonalnych. W rodzinach zastępczych spokrewnionych było 31951 dzieci, niezawodowych 15 486, a w zawodowych rodzinach zastępczych 6371 dzieci. Istotnym faktem wskazującym na poważą skalę zjawiska są dane pokazujące, że w 2015 r. do rodzin naturalnych z pieczy wróciło 4293 dzieci, a jednocześnie 12684 napłynęło. Próbą praktycznej odpowiedzi na ten problem jest wprowadzenie do systemu pomocowego, na mocy ustawy o wspieraniu rodziny i systemie pieczy zastępczej z 2011 r., nowego zawodu - asystenta rodziny. Intencją ustawodawcy było skoncentrowanie działań na rodzinie zagrożonej zabraniem dziecka i niedopuszczenie do jej dezintegracji ${ }^{2}$.

Wydaje się, że obecnie jesteśmy świadkami tworzenia się nowych paradygmatów pomocy i wspierania rodziny, a także opisu tychże zmian. Pedagogika, jak postuluje Oskar Szwabowski ${ }^{3}$, tworzy swoją tożsamość wokół pojęcia paradygmatu i w związku z tym refleksja nad paradygmatami nie powinna znajdować się na obrzeżach dyskursu naukowego, czy być zaliczana jedynie do spuścizny historycznej. Paradygmat będący „zbiorem ostatecznych przesłanek w wyjaśnianiu jakiegoś obszaru rzeczywistości przyjętych w społecznościach uczonych, a następnie upowszechniony jako wzór myślenia w normalnych zbiorowościach użytkowników nauki"4, stanowi podstawę rozumienia procesów, szczególnie w społeczeństwie, które doświadcza tak dynamicznych zmian. Ciekawa w tym kontekście jest uwaga Earla Babbiego, który twierdzi, że „w naukach społecznych teoretyczne paradygmaty mogą zyskiwać lub tracić popularność, lecz rzadko zostają odrzucone w całości [...]"5. Paradygmaty w naukach społecznych oferują różne perspektywy badania, opisywania i wyjaśniania procesów i zjawisk życia społecznego. Każda z nich uwzględnia pewne założenia metodo-

2 Por. M. Andrzejewski, Ewolucja pieczy zastępczej przez pryzmat nowych regulacji prawnych, „Teologia i Moralność” 2012, nr 11.

3 O. Szwabowski, Paradygmat i pedagogika, „Hybris” 2014, nr 25.

4 Z. Kwieciński, Tropy - ślady - próby. Studia i szkice z pedagogii pogranicza, Poznań-Olsztyn 2000, s. 53.

5 E. Babbie, Badania społeczne w praktyce, Warszawa 2003, s. 57. 
logiczne i strategie badawcze swoiste dla danego paradygmatu i nieobecne w pozostałych, a jednocześnie pomija wątki ujawniane gdzieś indziej. Ostatecznie paradygmaty nie są ani prawdziwe, ani fałszywe, a każdy z paradygmatów oferuje odmienny sposób patrzenia na życie społeczne i jego analizowania czy interpretowania. Paradygmat będzie pełnił więc podwójną funkcję. $Z$ jednej strony będzie stanowił podejście metodologiczne $\mathrm{w}$ badaniu nad rzeczywistością społeczną, a z drugiej pozwoli na założenie swoistego paradygmatycznego „filtru” pozwalającego na ogląd rzeczywistości z określonej perspektywy i tłumaczącego ją w określonym kontekście. Będzie on „fundamentalnym modelem lub układem odniesienia, który używamy, by uporządkować nasze obserwacje i rozumowanie" ${ }^{\prime}$. W kontekście rozważań o wsparciu i pomocy rodzinie istotne są wskazówki Zbigniewa Kwiecińskiego w odniesieniu do edukacji. Przekonuje on, że należy odrodzić i uczynić dostępnymi wiele z zapomnianych paradygmatów i teorii edukacyjnych po to, by móc spośród nich wybierać te najtrafniejsze i najskuteczniej służące rozwiązaniu wyzwań danego okresu i danej sytuacji. Aktualne staje się pytanie, który paradygmat będzie najbardziej odpowiedni, aby przezwyciężyć kryzys związany z dużą liczbą dzieci znajdujących się w pieczy zastępczej. Paradygmat będzie tu ujęty nie tylko jako ramy teoretyczne, ale także jako podejście wykorzystywane do konstruowania rozwiązań problemów społecznych. Może być także ogólną zasadą, kontekstem działania w ramach codziennej pracy pracowników socjalnych, kuratorów sądowych, asystentów rodziny czy koordynatorów pieczy zastępczej. Siatkę pojęciową w niniejszym artykule będą stanowić trzy paradygmaty: pajdocentryzm, familiocentryzm i paradygmat instytucjonalny, ze szczególnym naciskiem na paradygmat familiocentryczny.

O familiocentryzmie będziemy mówić w dwóch ujęciach: węższym i szerszym. Ujęcie węższe będzie określało relację (w kontekście relacji pomocowej), jaka występuje pomiędzy rodziną, a instytucją pomocową lub jej przedstawicielem. W takim ujęciu definicja familiocen-

${ }^{6}$ E. Kantowicz, Praca socjalna $w$ Europie. Inspiracje teoretyczne $i$ standardy ksztatcenia, Olsztyn 2005, s. 63.

7 Por. Z. Kwieciński, dz. cyt. 
tryzmu inspirowana pracami Reva Allena i Christophera Petra ${ }^{8}$ będzie brzmieć następująco:

Familiocentryzm jest podejściem określającym relacjeklienta/pacjenta/podopiecznego/ucznia i jego rodziny znajdujących się w sytuacji problemowej oraz systemu opieki, pomocy i wsparcia. Podejście to wskazuje na centralne miejsce rodziny w życiu każdego człowieka oraz systemu opieki, pomocy i wsparcia. Charakteryzuje się spostrzeganiem rodziny w kategoriach zasobów i silnych stron, a także wyposażeniem jej w taką wiedzę i umiejętności, która pozwoli na podejmowanie przez jej członków właściwych decyzji w swoich sprawach.

W zaprezentowanej definicji można wskazać na kilka kluczowych elementów. Cechami, na których zasadza się to pojęcie, są:

- odniesienie relacyjne rodziny do innych układów - w tym przypadku to profesjonalny system pomocy i wsparcia tworzony przez instytucje;

- umieszczenie rodziny jako kategorii centralnej, wyjaśniającej pozostałe elementy systemu;

- postrzeganie rodziny w kategoriach zasobów i silnych stron;

- posiadanie zdolności do podejmowania racjonalnych decyzji;

- posiadanie wystarczającej wiedzy i umiejętności pozwalających na podejmowanie decyzji.

Ujęcie szersze familiocentryzmu będzie opierać się na założeniu, że „istota ludzka może być zrozumiana i wspomagana jedynie w kontekście bliskich i znaczących systemów ludzkich, których sama jest częścią, spośród których najważniejszym jest rodzina"9.

Podejście familiocentryczne w sposób szczególny, choć czasem nieuświadamiany, obecne jest w dyskusjach dotyczących decyzji o umiesz-

8 R. I. Allen, Ch. G. Petr, Rethinking Family-Centered Practice, „American Journal of Orthopsychiatry" 1998, t. 68, nr 1.

9 Z. W. Stelmaszuk, Nowe spojrzenie na rodzinę, w: Współczesne kierunki w opiece nad dzieckiem. Wybór tekstów, pod red. Z. W. Stelmaszuka, Warszawa 1999, s. 11. 
czaniu dzieci w pieczy zastępczej. Literatura wskazuje na występujące napięcie związane z dwoma paradygmatami - pajdocentrycznym i familiocentrycznym ${ }^{10}$. W tym pierwszym priorytetem będzie zapewnienie bezpieczeństwa i właściwej opieki dziecku, w drugim najważniejszym zadaniem będzie zachowanie jedności rodziny. Dylemat ten często jest redukowany do uproszczonego pytania: co jest ważniejsze: dziecko czy rodzina? Bardziej racjonalne pytanie, stawiane zarówno przez teoretyków, jak i praktyków, koncentruje się na znalezieniu granicy pomiędzy zachowaniem integralności rodziny a zapewnieniem bezpieczeństwa, właściwej opieki i środowiska stymulującego rozwój dziecka. W wymiarze praktycznym w obszarze tym pojawią się następujące pytania: kiedy można zabrać dziecko z rodziny biologicznej? jak określić odpowiedni czas (nie za późno, nie za wcześnie) interwencji związanej z umieszczeniem w pieczy zastępczej? czy i do kiedy prowadzić pracę $\mathrm{z}$ rodziną biologiczną? co jest priorytetem pracy - powrót dziecka do rodziny, czy zapewnienie stabilnego miejsca jego pobytu do 18 roku życia?

Błędem logicznym wydaje się rozdzielanie dziecka i rodziny, jako dwóch całkowicie niezależnych podmiotów. Dziecko nie istnieje bez rodziny (nawet jeżeli ta rodzina nie wypełnia swoich funkcji prawidłowo), a także rodzina nie jest w stanie pozostać bez wpływu na pojawienie się nowego członka (nawet jeżeli dziecko jest oddane do adopcji). Jeżeli podejmiemy analizę w kontekście familiocentryzmu, będziemy rozpatrywać sytuację dziecka z punktu widzenia konkretnych uwarunkowań rodzinnych. W obecnej rzeczywistości często mamy do czynienia z podejmowaniem decyzji dotyczących samego dziecka, w myśl skrajnego paradygmatu pajdocentrycznego. Jak podkreśla Przemysław Gąsiorek, „W kontekście rodziny podkreśla się, że profesjonalne procedury skupiają się na indywidualnych osobach, nie

10 M. Kaczmarek, Zmiana paradygmatu $w$ opiece zastępczej. Uwagi do stanu reformy, w: Pomoc dzieciom i rodzinie $w$ środowisku lokalnym. Debata o nowym systemie, pod red. M. Racław-Markowskiej, Instytut Spraw Publicznych, Warszawa 2005; por. T. Sokołowski, Powrót dziecka do rodziny bądź fakultatywne pozbawienie władzy rodzicielskiej, „Ruch Prawniczy, Ekonomiczny i Socjologiczny” 2003, nr 3. 
biorąc pod uwagę znaczenia i zasobów rodziny"11. Należałoby zastanowić się, czy dla niektórych rodziców zabranie dziecka nie jest swoistego rodzaju uwolnieniem od konieczności bycia odpowiedzialnym za warunki materialne, psychiczne, rozwojowe, edukacyjne. Rodzice, których dziecko zostało umieszczone w pieczy zastępczej, często nie muszą podejmować trudnych decyzji, budować codziennej relacji z dzieckiem. Trzeba też podkreślić, że to dziecko, ofiara określonego stylu życia rodziców, jest umieszczone w nowym środowisku, często nowej szkole, wśród obcych osób. Jest odcięte od swojej naturalnej sieci rodzinnej (family network), przy czym rodzice są dalej osadzeni w tym samym środowisku. Można więc skonstatować, że w niektórych przypadkach zabranie dziecka będzie karą dla niego samego i swoistą „nagrodą" dla rodziców. Istotnym faktem jest, że samo zabranie dziecka nie rozwiązuje problemu rodziny. Rodzi się więc pytanie, co stanie się z kolejnymi dziećmi pojawiającymi się w rodzinie, jak będzie rokować sprawowanie opieki nad nimi.

Można wskazać, że u podstaw systemu pomocy w Polsce leży paradygmat pajdocentryczny. Służby społeczne są zobowiązane (prawnie, etycznie, społecznie) do działań wtedy, kiedy dobro dziecka jest zagrożone. Inaczej wygląda sprawa w przypadku osób dorosłych. Osoby dorosłe same odpowiadają za siebie i system nie ponosi odpowiedzialności za to, w jaki sposób dana osoba kształtuje swoje życie do momentu, kiedy jego działania nie naruszają granic innych osób. Dlatego dziecko, które jest zaniedbane, wymaga opieki, a dorosły bezdomny może skorzystać z pomocy, ale nie musi. Wydaje się, że kluczowe jest tu pytanie o to, czy dany dorosły w sposób odpowiedzialny kształtuje życie dzieci. W myśl teorii systemowej nie ma możliwości, aby zachowujący nawet bierną postawę dorosły funkcjonujący w rodzinie nie oddziaływał w żaden sposób na przybywające w niej dzieci. Realizując określony styl życia, podejmując zachowania ryzykowne, budując relację z dzieckiem w swoisty dla siebie sposób (brak relacji to także

11 P. Gąsiorek, Podejście skoncentrowane na rodzinie $w$ pedagogice społecznej - alternatywa wobec metodologicznego indywidualizmu, w: Rodzina, tożsamość, pamięć, pod red. M. Kujawskiej, I. Skórzyńskiej, G. Teusz, Poznań 2009, s. 83. 
sposób tworzenia realizacji relacji z dzieckiem - negatywny), pozostawia swój ślad w życiu dziecka, także w sytuacji, kiedy jest ono umieszczone w pieczy zastępczej.

Integrując obydwa paradygmaty: familiocentryczny i pajdocentryczny, można wskazać na konieczność zastosowania metody podwójnej decyzji - dotyczącej zarówno dziecka, jak i jego rodziny/rodziców. Takie podejście znosi podział pomiędzy dobrem dziecka a dobrem rodziny. Każda z decyzji podjęta w perspektywie familiocentrycznej musiałaby odnosić się zarówno do dziecka, jak i jego najbliższych ze szczególnym odniesieniem do rodziców. Takie podejście pozwalałoby na całościowe spojrzenie na problem i podjęcie próby jego realnego rozwiązania. Choć mamy tu jak gdyby dwa podmioty, to pojęcie dobra dziecka będzie zawierało się w pojęciu dobra rodziny.

Proces umieszczania dzieci w pieczy zastępczej może być analizowany także w szerszym, nieograniczonym do najbliższej rodziny, kontekście. Wydaje się, że dobrą podstawę teoretyczną może stanowić zestawienie paradygmatu familiocentrycznego z teorią ekologiczną Uriego Bronfenbrennera ${ }^{12}$. Wpisując familiocentryzm w teorię ekologiczną, widzimy, że w przypadku dzieci umieszczanych w pieczy zastępczej należy wziąć pod uwagę cały kontekst funkcjonowania dziecka i rodziny. Podejmowane w ich sprawie decyzje, sposoby wsparcia, pomocy będą wynikać nie tylko z bezpośredniej sytuacji, w jakiej znajduje się dziecko czy jego rodzice, ale z uwzględnieniem kontekstu kulturowego, prawnego i społecznego, które stwarza środowisko życia danej rodziny. Bronfenbrenner wskazuje, że to w środowisku znajdują się siły napędowe i źródła zmian rozwojowych dziecka ${ }^{13}$. Istotne więc w rozwiązywaniu problemów rodziny będzie nawiązanie relacji dziecka i rodziny z przedstawicielami, instytucjami każdego z poziomów prezentowanych w modelu ekologicznym. Pojęcie relacji, odniesienia jest jedną z podstawowych kategorii pozwalających na formułowanie rozwiązań. Relacyjność zakłada reakcyjność, współdziałanie, podsta-

12 U. Bronfenbrenner, The Ecology of Human Development. Experiments by nature and design, Cambridge 1979.

13 Tamże. 
wową otwartość na osiąganie wspólnych celów. Relacyjność to także działanie. Jak podkreśla Bronfenbrenner, dla skutecznej zmiany istotne jest podjęcie aktywności zarówno przez członków rodziny (chęć budowania relacji, zmiany), jak i środowiska (otwartość i wrażliwość na udzielanie pomocy i wsparcia). W sytuacji zagrożenia umieszczeniem dziecka $\mathrm{w}$ pieczy teoria ekologiczna pomaga w porządkowaniu modelu pomocowego. Proces ten powinien zacząć się od najbliższego środowiska rodziny. Okazuje się, że rodzina dalsza, sąsiedzi mogą stać się dla rodziny w kryzysie istotnym źródłem siły i wsparcia. Są to osoby, które znajdują się najbliżej rodziny, są z nimi obecne w codziennych sytuacjach, ale także obdarzane są na ogół relacją zaufania. $\mathrm{W}$ procesie zmian ważne więc będzie odniesienie się właśnie do nich i wykorzystanie potencjału mogącego pomóc rodzinie na zachowanie dzieci lub ich odzyskanie ${ }^{14}$.

Założenia teorii ekologicznej w kontekście systemu pomocy rodzinie można przestawić w formie diagramu, który będzie określał uwarunkowania, w jakich znajduje się rodzina potrzebująca pomocy. Dla rodziny istotne jest stworzenie relacji z osobami i instytucjami będącymi na różnych poziomach diagramu oraz podjęcie działań w konkretnej rzeczywistości, w jakiej rodzina się znajduje.

14 Por. C. A. Lietz, M. J. Hayes, T. W. Cronin, F. Julien-Chinn, Supporting Family-Centered Practice Through Supervision: An Evaluation of Strengths-Based Supervision, „Families in Society” 2014, t. 95, nr 4. 


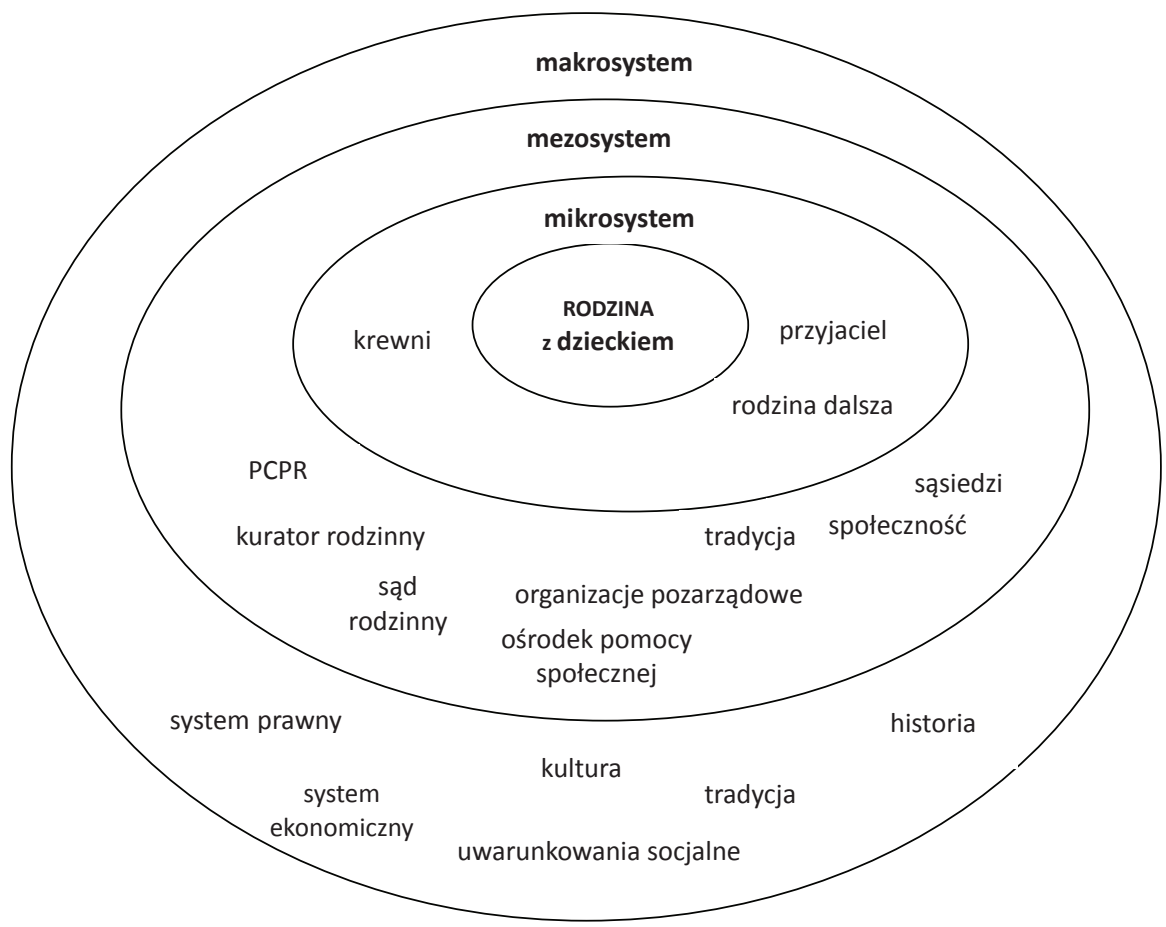

Schemat 1. System pomocy rodzinie w ujęciu teorii ekologicznej

Źródło: Opracowanie własne na postawieU. Bronfenbrenner, The Ecology of Human Development. Experiments by nature and design, Cambridge 1979.

Jak wskazuje diagram, centrum wszystkich oddziaływań stanowi rodzina. Dziecko jest integralnie wpisane w system rodzinny i choć konieczna jest wrażliwość na potrzeby poszczególnych osób (dzieci, mama, tata), to kluczowe wydaje się uczynienie podmiotem działania właśnie rodzinę. Podejście familiocentryczne będzie znacząco wpływało na sposób konstruowania poszczególnych poziomów modelu ekologicznego (od mikro- do makrosystemu). Odwrócona zostaje więc piramida, w której przy rozwiązywaniu problemów rodziny najistotniejsze są instytucje, a nie sama rodzina. $\mathrm{W}$ familiocentryzmie przyję- 
ta zostanie więc perspektywa od rodziny do makrosystemu. Obrazuje to diagram 2 .

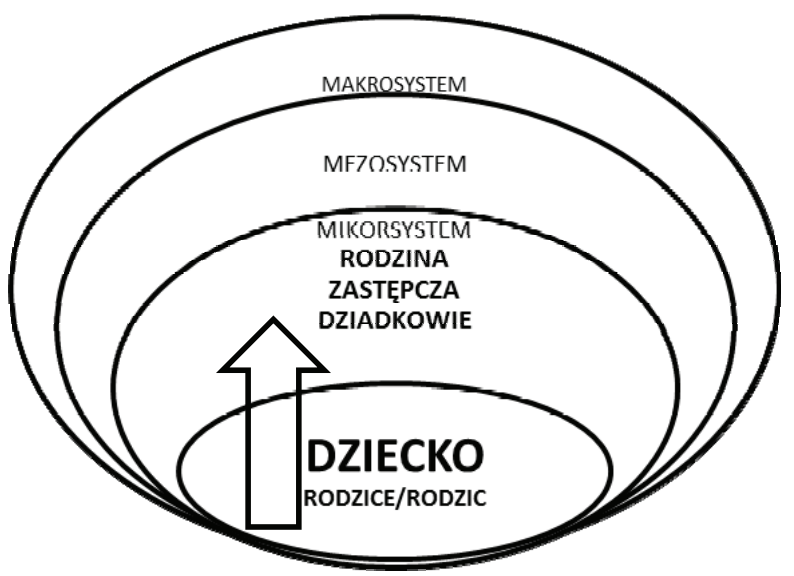

Schemat 2. Umieszczanie dzieci w spokrewnionej rodzinie zastępczej perspektywa ekologiczna

Źródło: opracowanie własne.

W wyniku łączenia teorii ekologicznej i podejścia familiocentryczngo powstaje nowy model pomocowy dla rodzin zagrożonych umieszczeniem dzieci w pieczy zastępczej. Będziemy tu mieli do czynienia z dwoma wymiarami: indywidualnym i systemowym.

W wymiarze pojedynczej rodziny familiocentryzm będzie wyznaczał określoną sekwencję działań. W obecnym systemie odpowiedzią na problem rodziny jest zaangażowanie instytucji, czyli przejście do mezosystemu. Należy także podkreślić, że rodzina nie znajduje się w centrum (nie podejmuje decyzji, odpowiedzialności), a rolę wiodącą w procesie przejmują instytucje. Jednocześnie to nie rodzina (jej charakter, historia, uwarunkowania) wpływa na stosowane metody, procedury, ale instytucja wdraża, często uniwersalne, metody postępowania dostosowane nie tyle do rodziny, ile raczej do kategorii problemu. Jak widać, w takim przypadku ominięte są też zasoby znajdujące się w obszarze mikrosystemu. 
Na poziomie budowania systemu zastosowanie perspektywy familiocentrycznej będzie wyznaczało sposób konstruowania rozwiązań na poszczególnych szczeblach. Jeżeli podstawową wartością stanie się zachowanie integralności rodziny, to powinno mieć swoje odzwierciedlenie na wszystkich etapach. Rozwiązania prawne i organizacyjne będą sprzyjać zachowaniu jedności rodziny, włączania najbliższych $\mathrm{w}$ pomoc $\mathrm{w}$ sytuacjach kryzysowych, prymatu rodziny $\mathrm{w}$ relacjach z instytucjami, wreszcie prawo, przekaz kulturowy będzie podkreślał wartość rodziny i jej centralne miejsce.

Należy podkreślić, że umieszczenie dziecka w pieczy zastępczej jest sytuacją wyjątkową i nie powinna to być normą ${ }^{15}$. W perspektywie familiocentrycznej i ekologicznej stanowi to poważne zaburzenie ekosystemu dziecka i rodziny. Biorąc pod uwagę rozwiązania prawne w Polsce, dziecko, które nie może przebywać w rodzinie biologicznej, jest umieszczone w instytucji opieki instytucjonalnej, rodzinnej (placówki) lub w rodzinach zastępczych - spokrewnionych, niezawodowych i zawodowych ${ }^{16}$. Sytuacją, która w najmniejszy sposób ingeruje w ekosystem rodziny, jest umieszczenie dziecka w rodzinie, która jest z nim spokrewniona, należy do jego mikrosystemu. W perspektywie familiocentrycznej w sytuacji takiej priorytetem będzie umieszczenie dziecka u rodziny bliższej lub dalszej. W Polsce zasadniczo większość dzieci w pieczy zastępczej przebywa u swoich bliskich, na ogół babć i dziadków. Jest to zgodne z paradygmatem familiocentrycznym, jednak rodzi poważne pytanie o jakość i trwałość takiego rozwiązania.

Badania nad stabilnością rodzin zastępczych wskazują, że w wielu przypadkach umieszczenie dziecka w rodzinie babci lub/i dziadka nie stanowi rozwiązania trwałego. Często dochodzi do sytuacji, kiedy dziadkowie, którzy wcześniej nie wypełniali prawidłowo funkcji rodzicielskich, stają się rodzinami zstępczymi dla swoich wnuków. W badaniach porównawczych spokrewnionych i zawodowych rodzin zastępczych w Wielkiej Brytanii ${ }^{17}$ wyniki wykazały, że w rodzinach za-

15 Por. M. Andrzejewski, dz. cyt.

16 Por. Ustawa o wspieraniu rodziny i systemie pieczy zastępczej z dnia 9 czerwca $2011 \mathrm{r}$.

17 I. Sinclair, Fostering now. Messages from research, Londyn, Filadelfia 2005. 
wodowych dzieci mają zapewnione lepsze warunki do rozwoju, rodzice zastępczy są bardziej stymulujący i prezentują prawidłowe postawy rodzicielskie. Ważne więc będzie, po pierwsze, jaką perspektywę zastosujemy do oceny sytuacji dziecka (rodziny), po drugie, w jakim paradygmacie będą prowadzone badania. Rodzice, którzy przeszli procedurę kwalifikacyjną, ukończyli kursy, są wspierani i kontrolowani na bieżąco przez instytucje, mogą stanowić dla dziecka bardziej rozwojowe środowisko. Jednak z perspektywy familiocentrycznej istotne będzie nie tylko osiąganie sukcesów w szkole, ale także inne wymiary: poczucie własnej tożsamości, posiadania sieci społecznej czy też doświadczenie akceptacji, miłości - czyli wartości, które określają rodzinę w sposób rudymentarny.

Przy umieszczaniu dzieci w rodzinach zastępczych dziadków widzimy perspektywę familiocentryczną, ale jakby zatrzymaną w połowie drogi. Pierwszy krok - utrzymanie dziecka w ekosystemie rodzinny - zostaje dokonany. Jednak brakuje oddziaływania koncepcji familiocentrycznej na kolejne poziomy systemu, w którym funkcjonuje rodzina. Mikrosystem to rodzina dalsza, sąsiedzi, bliscy. W Polsce przy ustanawianiu rodziny zastępczej obowiązuje model odpowiedzialności, w którym występują trzy podmioty: sąd (ewentualnie kurator), PCPR (lub MOPR w miastach na prawach powiatu) oraz rodzic zastępczy (babcia, dziadek). Ponieważ utworzenie rodziny zastępczej wiąże się z otrzymywaniem środków na pokrycie kosztów dziecka, często dochodzi do sytuacji, w której w danej rodzinie odpowiedzialną za losy dziecka/dzieci jest tylko ta osoba otrzymująca wynagrodzenie. Warto $\mathrm{w}$ tym miejscu podkreślić, że rodzice zastępczy spokrewnieni nie otrzymują wynagrodzenia, a jedynie pokrycie kosztów pobytu u nich dziecka. W wielu systemach prawnych współodpowiedzialność za rozwój dziecka ponosi większa liczba członków rodziny (ciocie, wujkowie, kuzyni, rodzice chrzestni itp.), a w małych społecznościach często także sąsiedzi, przyjaciele, którzy stanowią istotne źródło wsparcia dla dzieci i rodziców zastępczych. Badania ${ }^{18}$ wskazują, że możliwe jest

18 J. Przeperski, Konferencja grupy rodzinnej $w$ teorii i praktyce pracy socjalnej z rodzina, Toruń 2015. 
zaangażowanie rodziny dalszej tak, by była realnym zasobem i często kompensowała braki związane np. z wiekiem u dziadków.

Podejście familiocentryczne będzie także zmieniało system na poziomie mezosystemu. Dzisiaj brakuje realnego wsparcia dla rodzin, dzieci, które często borykają się z wieloma problemami. Pracownicy socjalni i kuratorzy dziwią się problemom, które wydają się naturalne. Problemy młodzieży w okresie dojrzewana nakładające się na postępujący wiek i niewydolność dziadków jest procesem naturalnym. Jednak system nie jest przygotowany (w duchu familiocentryzmu znając fazy cyklu rodzinnego) na działania profilaktyczne, podejmując niejednokrotne działania interwencyjne, które nie są w stanie cofnąć i rozwiązać nabrzmiałych problemów. Jednocześnie w systemie powinny zostać uruchomione takie działania, które kompensowałyby braki lub niedostatek czynników rozwojowych dla dzieci, zmniejszałyby napięcie związane z powtórnym wejściem w rolę rodziców i przymusową rezygnację z roli dziadków przez rodziców zastępczych.

Dużo trudniejsze zadanie pojawia się w sytuacji, kiedy dziecko zostaje umieszczone w rodzinie zastępczej, w której opiekunowie są dla dziecka osobami obcymi.

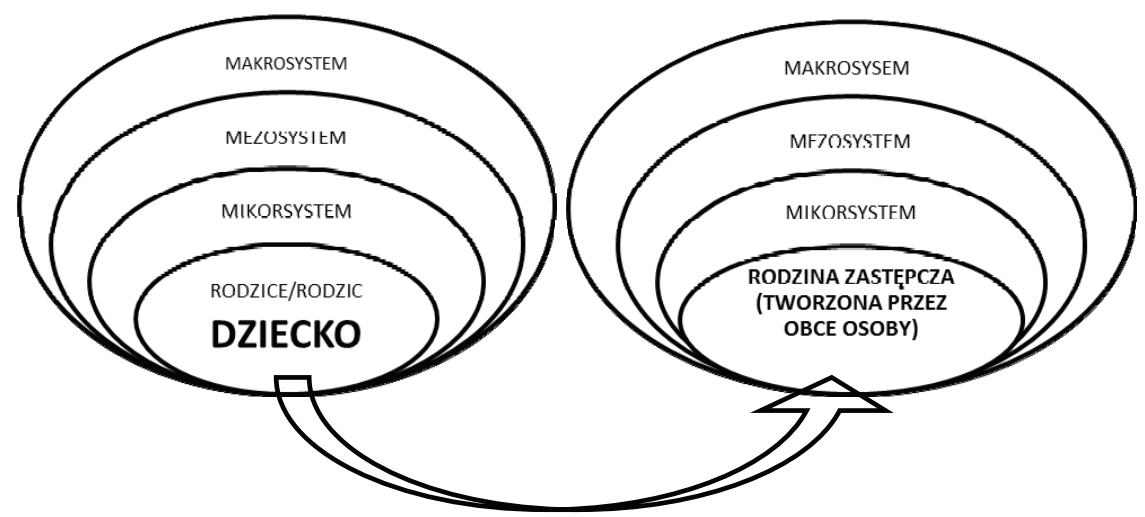

Schemat 3. Umieszczanie dzieci w pieczy zastępczej niespokrewnionej lub instytucjonalnej w perspektywie ekologicznej

Źródło: opracowanie własne. 
Na początek należałoby podkreślić, że dziecko jest przenoszone do całkowicie innego ekosystemu, zostaje całkowicie wyrwane ze swojego środowiska. Występują oczywiście sytuacje, kiedy środowisko (poziom rodziny i mikrosystemu) stanowi dla dziecka źródło zagrożenia i wtedy odizolowanie i przeniesienie $\mathrm{w}$ nowe środowisko wydaje się zasadne. Jednak musimy pamiętać, że mówimy tu o pieczy zastępczej, która co do zasady jest czasowa i w większości przypadków nie tylko jest zobowiązana do opieki nad dzieckiem, ale także do podtrzymywania kontaktów z jego rodziną biologiczną ${ }^{19}$. W tym przypadku praca systemu w momencie decyzji o umieszczeniu jest de facto redukowana do funkcji kontrolnych. Rodzice są wyłączeni, nie są także wykorzystane zasoby tkwiące w szerszym systemie rodziny biologicznej.

W ujęciu systemowym, ekologicznym istotne będzie pytanie o relacje poszczególnych instytucji, bliskich, sąsiadów, rodziców kolegów ze szkoły wobec dziecka umieszczonego w rodzinie poza swoim środowiskiem. W praktyce są one całkowicie marginalizowane, a jedyną relacją, jaka pozostaje, jest ta do rodziców, którzy często na tym etapie swojego życia, pozostawieni bez wsparcia, nie zapewniają tym kontaktom odpowiedniej jakości. W ujęciu familiocentrycznym istotne będzie zaangażowanie dziadków, cioć, wujków w budowanie wartościowych relacji z dzieckiem.

Podobna sytuacja będzie w przypadku umieszczenia dziecka w instytucjonalnej pieczy zastępczejej ${ }^{20}$. Obecnie główne działania placówek w stosunku do rodziców koncentrują się na uregulowaniu urlopowań dzieci do domów oraz organizacji imprez i spotkań okolicznościowych. Przeformułowując system w duchu teorii ekologicznej i paradygmatu familiocentrycznego istotne będzie włączenie rodziców w codzienne funkcjonowanie dziecka, przeniesienie ciężaru odpowiedzialności na rodziców (chyba że zostali pozbawieni praw rodzicielskich), a także zmiana sposobu funkcjonowania - dziecko, kiedy tylko może, przebywa w domu, a instytucja jest rzeczywistością zastępczą, kiedy warun-

19 Ustawa o wspieraniu rodziny i systemie pieczy zastępczej z dnia 9 czerwca $2011 \mathrm{r}$.

20 Por. E. M. W. Geurts, J. Boddy, M. J. Noom, E. J. Knorth, Family-centred residential care: The new reality?, „Child and Family Social Work” 2012, nr 17. 
ki nie pozwalają dziecku na przebywanie z rodzicami. Postulat taki nie wydaje się abstrakcyjny wobec liczby dzieci, które są urlopowane do domów rodzinnych na czas wolny od nauki szkolnej. Istotne będzie także włączenie w relację z placówką osób ważnych dla dziecka z poziomu mikro- i mezosystemu. Możliwe jest włączenie nie tylko rodziców, ale także członków szerszej sieci społecznej dziecka (cioć, wujków, dziadków, kuzynów itp.) w codzienny plan zajęć w placówce, takich jak odrabianie lekcji, spacery. Kontakt tych osób z dzieckiem pozwala na podtrzymanie jego więzi ze swoim pierwotnym ekosystemem, podnosi motywację do oczekiwanych zachowań. W takiej sytuacji także rodzice podlegają oddziaływaniu przedstawicieli mikro- i mezosystemu. Zaangażowanie w relację z dzieckiem powoduje na ogół mocniejszy nacisk na rodziców, by pokierowali swoim życiem w sposób umożliwiający powrót dziecka do swojej rodziny.

Koncepcja familiocentryczna będzie także sprawdzać się w sytuacji wsparcia rodziny zastępczej, która nie jest spokrewniona z dzieckiem. Ważnym elementem może okazać się zaangażowanie rodziny dalszej, bliskich w pomoc rodzicom zastępczym, np. umożliwienie spędzenia przynajmniej jednego wspólnego małżeńskiego wieczoru w tygodniu, odciążenie w codziennych czynnościach przy dzieciach. Należy podkreślić, że pomoc ze strony bliskich nie powinna wynikać z nakazu prawnego, lecz z poczucia odpowiedzialności za członków swojej rodziny.

Familiocentryzm jako paradygmat może być sposobem na wyjaśnianie, jak i konstruowanie nowych podejść w obszarze wsparcia i pomocy rodzinom. Może stanowić alternatywę dla tradycyjnego systemu opartego na paradygmacie medycznym, wskazującym przede wszystkim deficyty rodziny. Zasygnalizowane w artykule rozwiązania mają charakter próby eksploracji nowych pól na gruncie polskiej pedagogiki społecznej i pracy socjalnej. Dlatego istotnym będzie podjęcie dalszych studiów i badań nad możliwością wpisania kategorii paradygmatu familiocentrycznego w teorię zarówno pracy socjalnej, pedagogiki rodziny, jak i pedagogiki społecznej. 


\section{Streszczenie}

NOWE PARADYGMATY W OBSZARZE WSPARCIA RODZINY W ŚRODOWISKU LOKALNYM W PERSPEKTYWIE UMIESZCZANIA DZIECI W PIECZY ZASTĘPCZEJ

W pieczy zastępczej w Polsce na koniec 2015 roku znajdowało się ponad 77 tysięcy dzieci. Dotychczasowy model pomocowy wydaje się mało efektywny i nie prowadzi do osiągnięcia głównego celu, jakim jest znaczące zmniejszenie liczby dzieci przebywających w opiece poza rodzinami biologicznymi. W prezentowanym artykule została podjęta refleksja nad przeformułowaniem paradygmatu wspierania oraz pomocy rodzinom, które są zagrożone lub pozbawione możliwości wychowywania własnych dzieci. Umieszczenie rodziny w centrum projektowania i realizacji działań pomocowych jest jednym z wyznaczników nowej perspektywy w pieczy zastępczej. W literaturze przedmiotu jest ona zdefiniowana jako paradygmat familiocentryczny. Analiza poszczególnych form pieczy zastępczej w świetle prezentowanej koncepcji pozwoliła na sformułowanie wniosków praktycznych i teoretycznych. Mogą one zarówno zostać zastosowane przy tworzeniu, optymalizacji lokalnych programów wspierania rodziny, jak i inspirować do stawiania nowych pytań badawczych w obszarze pedagogiki społecznej, pedagogiki rodziny czy pracy socjalnej.

Słowa kluczowe: rodzina; piecza zastępcza; familiocentryzm; system pomocy rodzinie

\section{Summary}

NEW PARADIGMS IN THE AREA OF FAMILY SUPPORT IN THE LOCAL ENVIRONMENT WITH THE PROSPECT OF PLACING CHILDREN IN FOSTER CARE

At the end of 2015 there were more than 77,000 children in foster care in Poland. The former aid model appears to be ineffective and does not lead to the primary goal of significantly reducing the number of children in foster care. In this article, we have proposed a new paradigm in support families in need. Placing a family in the center of project and implementation of support is one of the determinants of the new perspective in foster care. In literature 
this paradigm is defined as a family-centered. The analysis of different types of foster care in family-centered paradigm allowed us to formulate practical and theoretical conclusions. They can be used both to create and optimize local family support programs and to inspire new research questions in the areas of social pedagogy, family pedagogy and social work.

Keyword s: family; foster care; family-centered; family welfare system 
